\title{
Some Biological Characteristics of the Primorsky Scallop Cultivated in the Area of the Oil Terminal in Kozmino Bay (Nakhodka Bay, Sea of Japan)
}

\author{
Inga Vladimirovna Matrosova ${ }^{1 *}$, Tatyana Sergeevna Kovaleva ${ }^{1}$ \\ ${ }^{1}$ Far Eastern State Technical Fisheries University, Engineering Disciplines Department, 52 B \\ Lugovaya Str., Vladivostok 690087, Russia
}

\begin{abstract}
Monitoring of the impact of the production activities of oil ports on the water area in general and on the hydrobionts living there, in particular, is a subject of the great attention. Some biological characteristics of the Primorsky scallop, grown by the hanging method at the experimental site in the conditions of the Kozmino bay were studied. Individuals of the same age of different generations were subjected to biological analysis. A comparative study of the size and weight characteristics showed that in the 2016 generation, the average shell height was higher, but the average total mass was higher in the 2015 generation of mollusks, which is due to the uneven growth of the shell of mollusks. Based on the research, it can be concluded that the size and weight characteristics correspond to the standard growth indicators for the scallop of the studied age groups, which indicates favorable living conditions for cultivated mollusks.
\end{abstract}

\section{Introduction}

Special marine oil port Kozmino Ltd. is located in the water area of the Kozmino bay of the Sea of Japan and, in terms of environmental impact, is a potentially hazardous facility that requires regular monitoring in order to timely identify and eliminate possible pollution. The monitoring program of the impact of the oil port's production activity on the natural ecosystem of Kozmino bay included monitoring of the state of the Primorsky scallop, which allows monitoring the state of the environment and is one of the methods for assessing and controlling the industrial pollution [1-7]. Marine invertebrates are known to be influenced by pollution and other unfavorable environmental factors throughout their entire life cycle [822].

In October 2010, to conduct biomonitoring in the water area of Kozmino bay, an experimental test farm was built in 250 meters from the oil terminal for the cultivation of marine hydrobionts [1]. 10,000 Primorsky scallops were planted in the cages, which became the basis for the future mariculture site. The planting of the scallop and the installation of the ridges of the landfill were carried out by specialists from the Pacific Institute of Bioorganic

* Corresponding author: Matrosova.IV@dgtru.ru 
Chemistry, Far Eastern Branch of the Russian Academy of Sciences. They also carried out the first study in 2010 to assess the ecological state of the water area, taking samples of soil, sea water, and scallop tissues (after a month's exposure in the cages of the landfill) [1]. Monitoring of the state of the water area of the Kozmino bay is carried out regularly [1, 3, 6, 7].

A goal of the research was to study some biological characteristics of the Primorsky scallop, grown by the hanging method in the conditions of the Kozmino bay in 2015 - 2018 .

To achieve this goal, it was necessary to study the size and weight composition, to characterize the dependence of shell height - total mass, to study the gender ratio and to compare some biological parameters of the scallop of the studied generations.

\section{Research materials and methods}

This study is based on the data collected in part by the author and employees of the OGBTS Transneft "Port-Kozmino" service area, at the experimental training ground for growing the hydrobionts, located in the Kozmino bay. Kozmino bay juts out into the eastern shore of Nakhodka Bay between Kozmino and Krylov capes, which protrude 1.9 and 2.8 miles northwest of Petrovsky cape, respectively. Nakhodka Bay is a bay in the eastern part of the Peter the Great Bay (in the Sea of Japan), located between Sredny and Krylov capes.

In the Kozmino bay, at the mariculture site, two hydro-biotechnical installations with cages for growing a scallop, were mounted near the port oil pier taking into account the current biotechnologies [23-30].

100 individuals of two generations - 2015 and 2016 - were taken for biological analysis. The shell height, total mass of the mollusk, shell mass, and age were determined for the samples of the coastal scallop.

Linear data were measured with a vernier caliper with an accuracy of $1 \mathrm{~mm}$. The mass of the scallop was determined using a balance with an accuracy of $1 \mathrm{~g}$.

\section{Research results}

Within the framework of monitoring the scallop condition, in response to changing environmental conditions, a comparison is usually made of individuals of the same age of different generations. For this, individuals of each generation are selected annually and their size and weight characteristics are determined. Based on the data obtained, the average values of the shell height and weight of the individual are calculated.

\subsection{Dimensional composition}

In 2015, the size of the yearlings of the Primorsky scallop from Kozmino bay varied in the range of 31-51 mm; the average value of the shell height was $41.5 \mathrm{~mm}$, individuals with a size of 39-43 mm prevailed in the modal class (Table 1), they accounted for $38 \%$. In the 2015 generation, the shell sizes of two-year-old scallops were $67-93 \mathrm{~mm}$; the modal class was dominated by individuals with a shell height of 74-79 $\mathrm{mm}(36 \%)$ (Table 1). Three-year-olds had shell heights of $85-126 \mathrm{~mm}$. Mollusks with a size of 105-114 mm predominated, accounting for $52 \%$. (Table 1 ).

In the 2016 generation of the coastal scallop, individuals with a shell sizes of $37-51 \mathrm{~mm}$ were observed among yearlings. The modal class consisted of mollusks of 44-48 mm, 57\% (Table 1). The shell sizes of two-year-olds of the same generation were $59-94 \mathrm{~mm}$, the average value was $82.9 \pm 0.51 \mathrm{~mm}$. Mollusks with a heights of $80-84 \mathrm{~mm}(38 \%)$ 
predominated. Three-year-olds had shell heights of $90-132 \mathrm{~mm}$, about $50 \%$ of the total number of mollusks accounted for individuals with a size of 105-114 mm (Table 1).

Table 1. Primorsky scallop shell height, $\mathrm{mm}$.

\begin{tabular}{|c|c|c|c|c|}
\hline $\begin{array}{c}\text { Generation of } \\
2015\end{array}$ & $\mathbf{n , ~ i n d . ~}$ & $\mathbf{X} \mathbf{m a x}$ & $\mathbf{X} \mathbf{m i n}$ & $\mathbf{\mathbf { x }} \pm \mathbf{m x}$ \\
\cline { 2 - 5 } & 100 & 52 & 31 & $41,5 \pm 0,29$ \\
\cline { 2 - 5 } & 100 & 93 & 67 & $78,9 \pm 0,5$ \\
\cline { 2 - 5 } & 100 & 126 & 85 & $109,7 \pm 0,69$ \\
\hline $\begin{array}{c}\text { Generation of } \\
2016\end{array}$ & 100 & 51 & 37 & $83,6 \pm 0,21$ \\
\cline { 2 - 5 } & 100 & 94 & 59 & $111,4 \pm 0,68$ \\
\cline { 2 - 5 } & 100 & 132 & 90 & $82,9 \pm 0,51$ \\
\hline
\end{tabular}

\subsection{Weight composition}

The weight composition of the yearlings of the Primorsky scallop from Kozmino bay in the 2015 generation varied from 20 to $43 \mathrm{~g}$, the modal class was formed by mollusks weighing 35-39 g (28\%) (Table 2). In two-year-olds, the weight varied from 54 to $135 \mathrm{~g}$, individuals with a weight of $80-99 \mathrm{~g}(26 \%)$ dominated (Table 2). Three-year-olds had a mass of 79-287 $\mathrm{g}$, the modal class included mollusks weighing 170-199 $\mathrm{g} \mathrm{(41 \% ).}$

In the 2016 generation, yearlings weighed from 21 to $40 \mathrm{~g}$, mollusks with a weight of 20$34 \mathrm{~g}$ dominated (36\%) (Table 2). Two-year-olds of the same generation, weighed from 43 to $103 \mathrm{~g}$. The modal class was represented by specimens of $70-79 \mathrm{~g}$, they accounted for $47 \%$. The weights of three-year-olds varied in the range of 118-332 $\mathrm{g}$, the dominant size group was represented in weight from 170 to $199 \mathrm{~g}(37 \%)$.

Table 2. Total mass of Primorsky scallop, g.

\begin{tabular}{|c|c|c|c|c|}
\hline Generation of & $\mathbf{n}$ (ind.) & $\mathbf{X ~ m a x}$ & $\mathbf{X}$ min & $\mathbf{x} \pm \mathbf{~ m}$ \\
\cline { 2 - 5 } 2015 & 100 & 43 & 20 & $31,9 \pm 0,4$ \\
\cline { 2 - 5 } & 100 & 135 & 54 & $87,2 \pm 1,3$ \\
\cline { 2 - 5 } & 100 & 287 & 79 & $190,1 \pm 3$ \\
\hline \multirow{3}{*}{$\begin{array}{c}\text { Generation of } \\
2016\end{array}$} & 100 & 40 & 21 & $30,9 \pm 0,3$ \\
\cline { 2 - 5 } & 100 & 103 & 43 & $80,8 \pm 0,6$ \\
\cline { 2 - 5 } & 100 & 332 & 118 & $202,5 \pm 3$ \\
& & & & \\
\hline
\end{tabular}

\subsection{Shell height - total mass dependence}

The dependence of shell height - total mass in the studied generations is described by power equations with a high approximation coefficient (Fig. 1-6).

The overwhelming majority of yearlings of the 2015 generation with a shell heights of 30 to $50 \mathrm{~mm}$ had a mass of 25 to $40 \mathrm{~g}$ (Fig. 1), two-year olds - from 66 to $90 \mathrm{~mm}$ with a mass of 60 to $120 \mathrm{~g}$ (Fig. 3). Three-year-olds with shell heights of 98 to $128 \mathrm{~mm}$ had a mass of 120 to $280 \mathrm{~g}$ (Fig. 5). 
The generation of 2016 was dominated by yearlings, whose weight varied from 25 to 40 $\mathrm{g}$ at a shell height of 40 to $50 \mathrm{~mm}$ (Fig. 2). Among two-year-olds, mollusks with shell heights of 70 to $98 \mathrm{~mm}$ prevailed (Fig. 4), weighing from 70 to $100 \mathrm{~g}$, and three-year-olds of the same generation had heights of 100 to $130 \mathrm{~mm}$ and a mass of 150 to $275 \mathrm{~g}$ (Fig. 6).

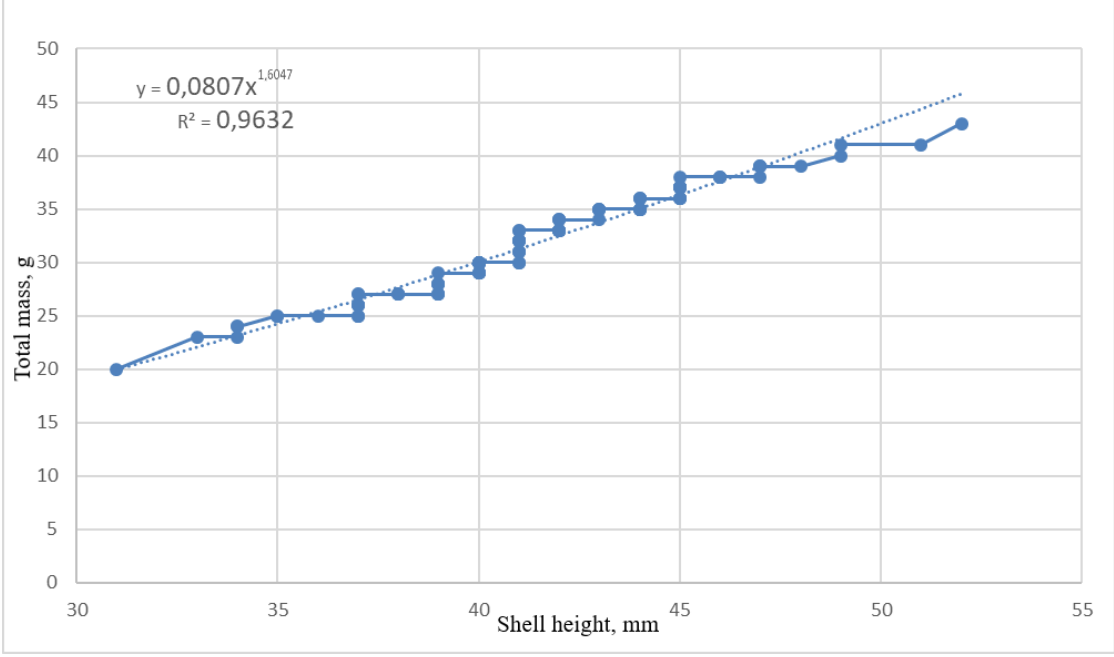

Fig. 1. Dependence of shell height - total mass of the scallop of the 2015 generation (yearlings)

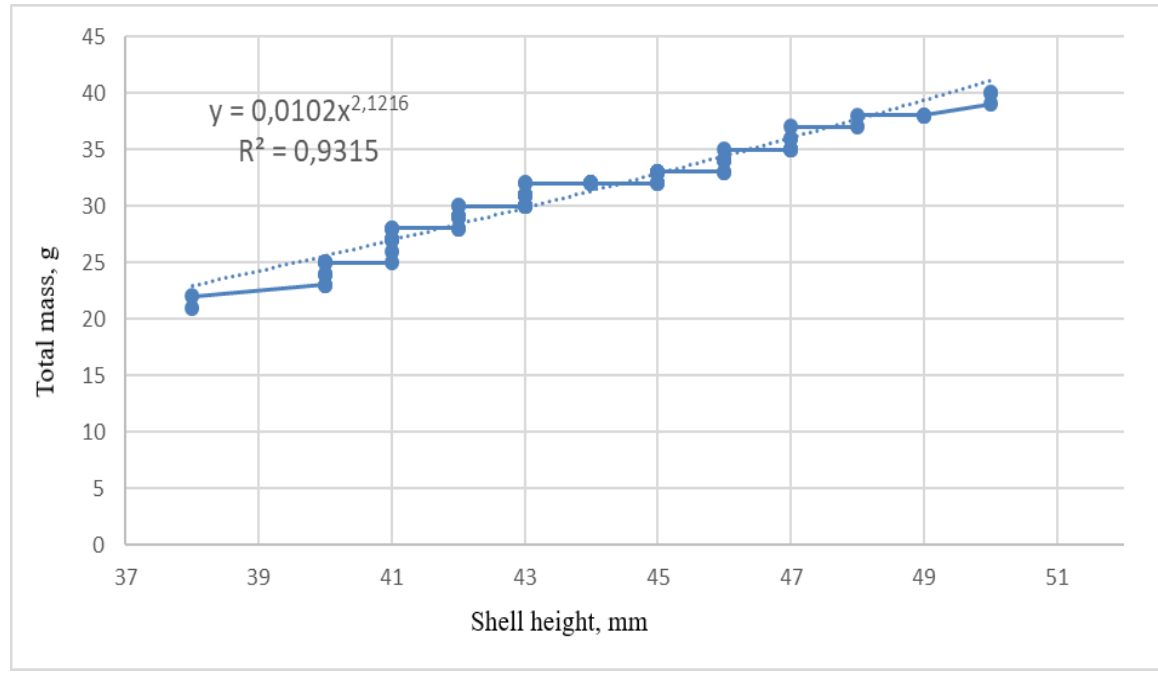

Fig. 2. Dependence of shell height - total mass of the scallop of the 2016 generation (yearlings) 


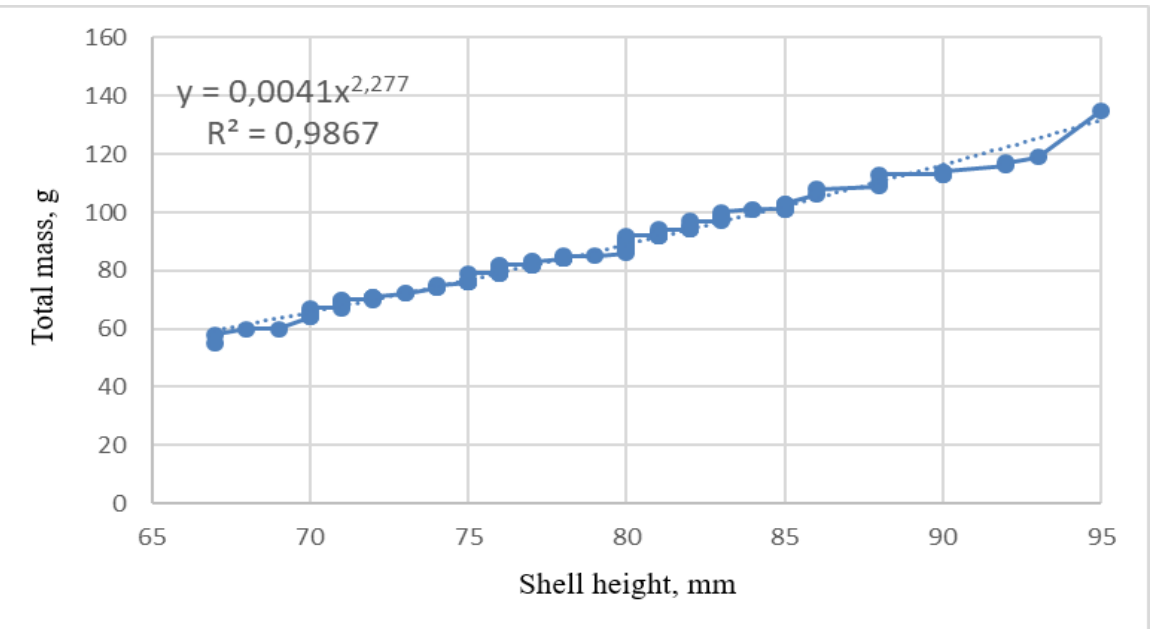

Fig. 3. Dependence of shell height - total mass of the scallop of the 2015 generation (two-year-olds)

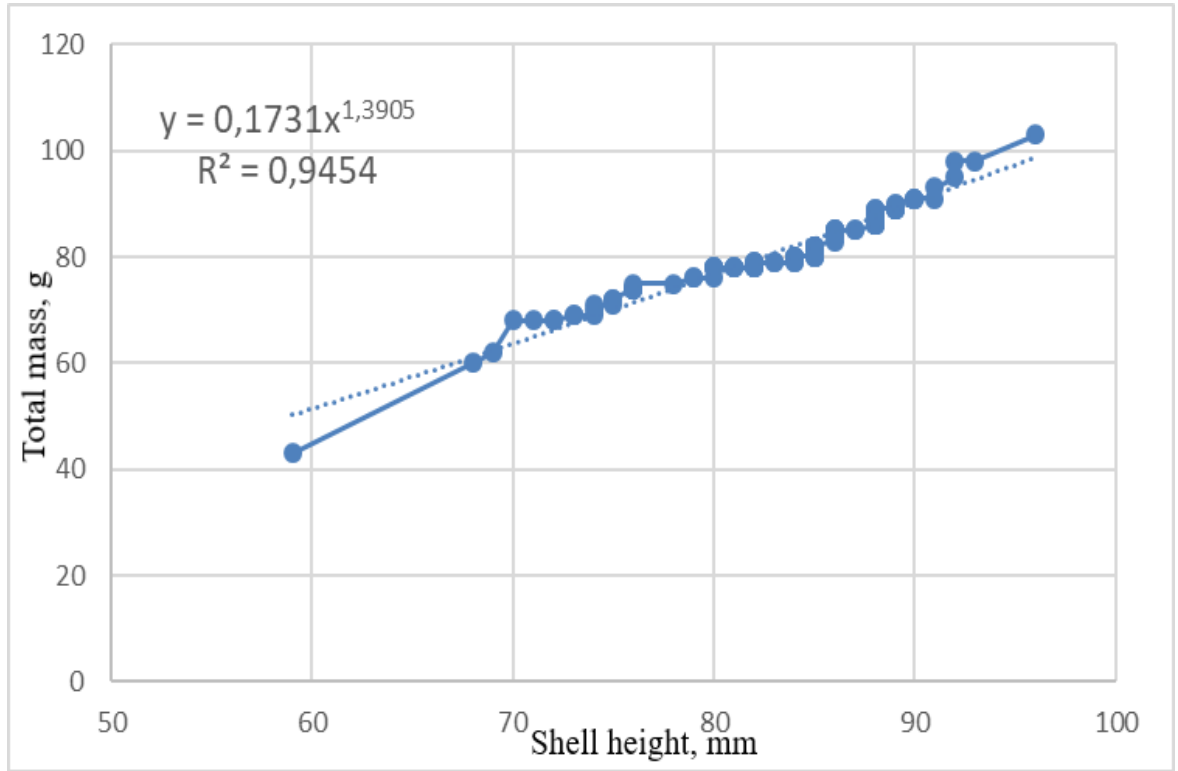

Fig. 4. Dependence of shell height - total mass of the scallop of the 2016 generation (two-year-olds) 


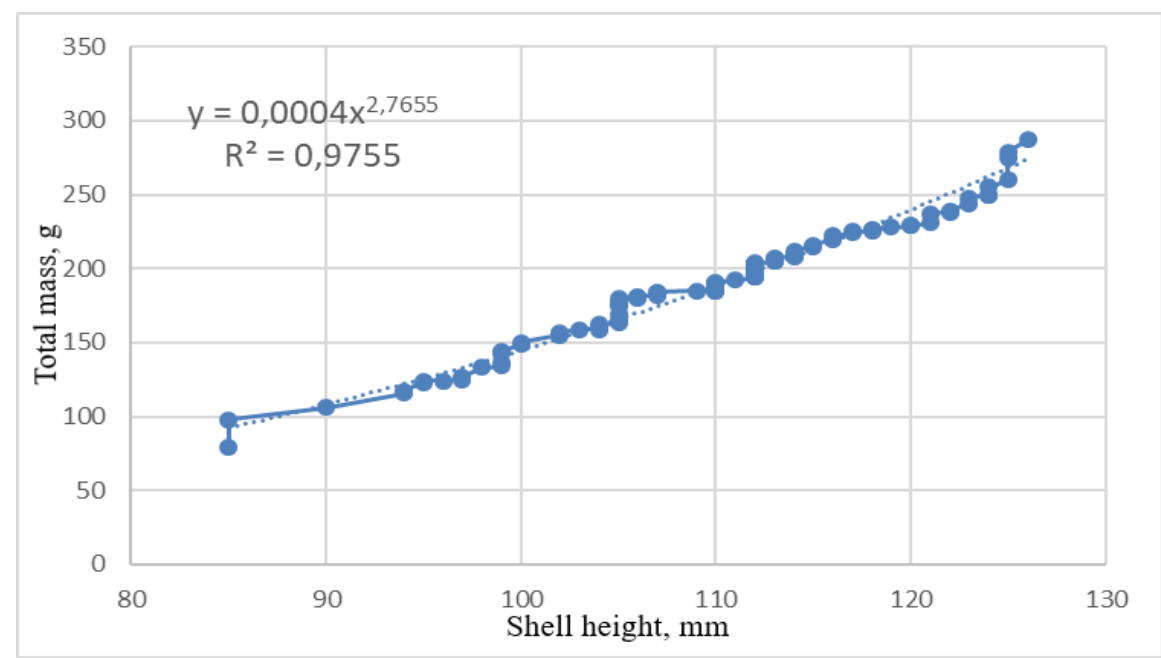

Fig. 5. Dependence of shell height - total mass of the scallop of the 2015 generation (three-year-olds)

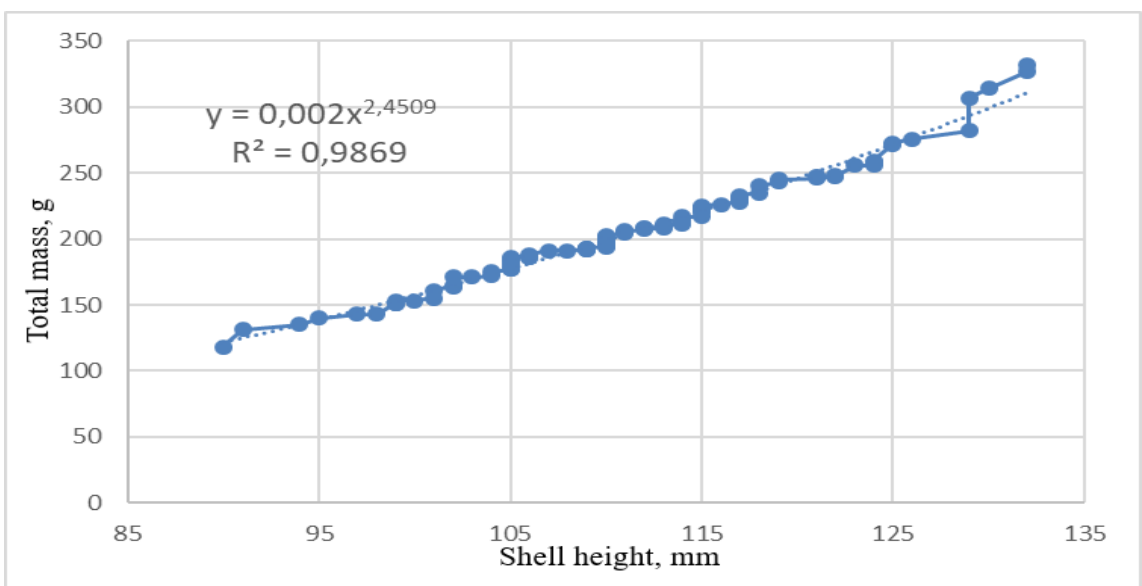

Fig. 6. Dependence of shell height - total mass of the scallop of the 2016 generation (three-year-olds)

\subsection{Gender ratio}

Gender was not determined in the yearlings of the Primorsky scallop; therefore, the ratio was analyzed only for two- and three-year-olds of both generations. In the 2015 generation, males prevailed in two-year-olds $(60 \%)$; among three-year-olds, females dominated, they accounted for $80 \%$. In the 2016 generation, among two-year-olds, most individuals were males $(60 \%)$, among three-year-olds, females prevailed, they also accounted for $60 \%$.

\subsection{Comparison of some biological parameters of the Primorsky scallop of the studied generations}

Comparative analysis of some size and weight indicators of the Primorsky scallop in Kozmino bay showed that the higher values of the shell height in yearlings were in the 2016 generation; they exceeded the average value by $4 \mathrm{~mm}$ (Fig. 7, Table 1). Two-year-olds were also higher in the 2016 generation, they exceeded two-year-olds of the 2015 generation by 4 $\mathrm{mm}$ (Fig. 8, Table 1). In comparison, according to the average indicators of three-year-olds, 
the shell height was also dominated by mollusks of the 2016 generation, their height exceeded the three-year-olds of the 2015 generation by $1.7 \mathrm{~mm}$ (Fig. 9, Table 1).

Despite the fact that the shell height of the yearlings of the Primorsky scallop was higher for individuals of the 2016 generation, the difference in weight between generations was insignificant, only $1 \mathrm{~g}$ (Fig. 10, Table 2). Also, with a lower shell height of two-year-olds of the 2015 generation, according to the average indicators of the total mass, they turned out to be $6.4 \mathrm{~g}$ more (Fig. 11, Table 2). Comparative characteristics of the average values of the total mass of three-year-olds of the studied generations showed that in the 2016 generation, mollusks were heavier by $12.7 \mathrm{~g}$ (Fig. 12, Table 2).

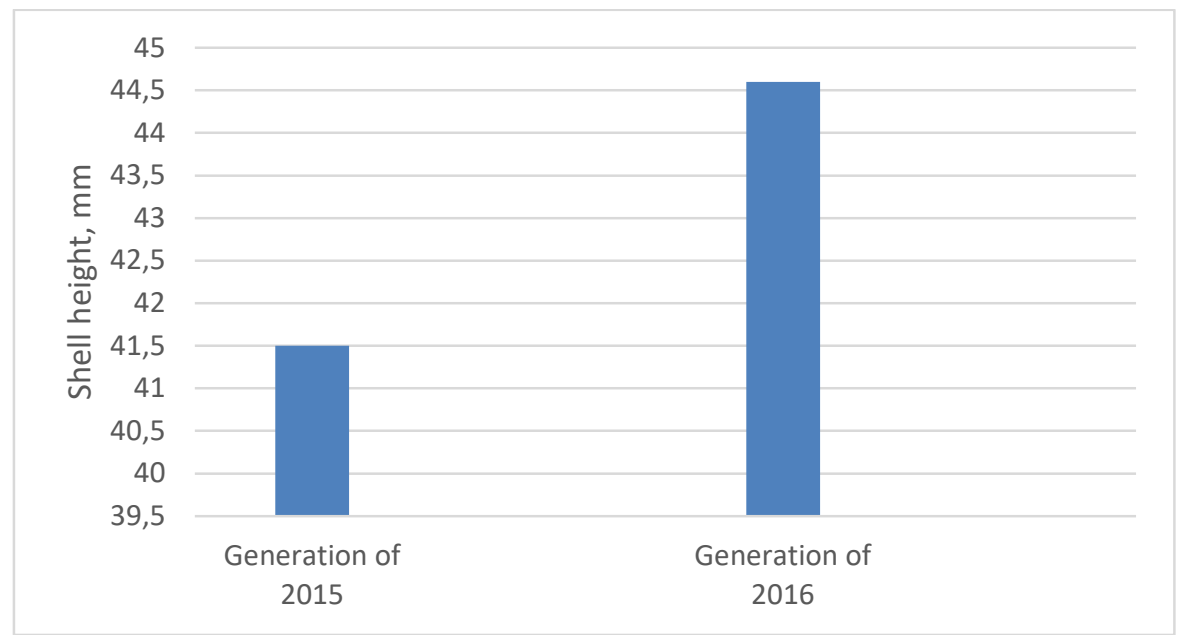

Fig. 7. Average shell heights of the scallop yearlings

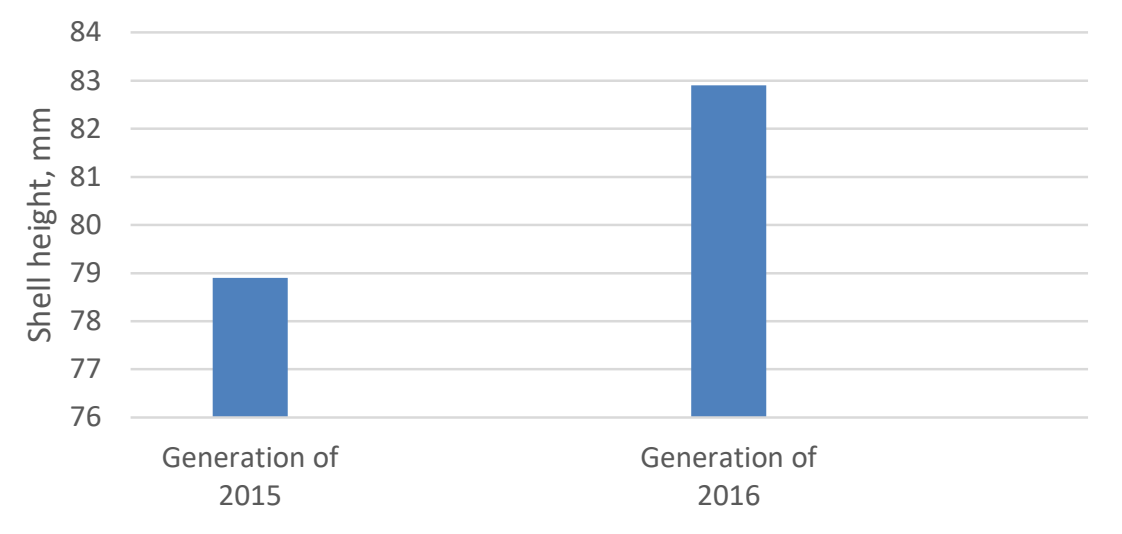

Fig. 8. Average shell heights of two-year-old scallops 


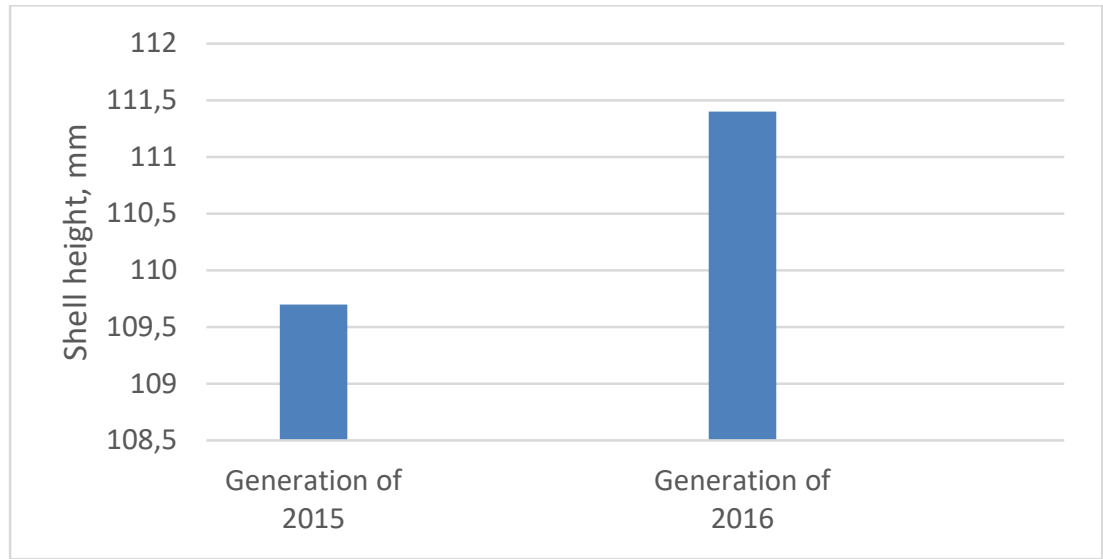

Fig. 9. Average shell heights of three-year-old scallops

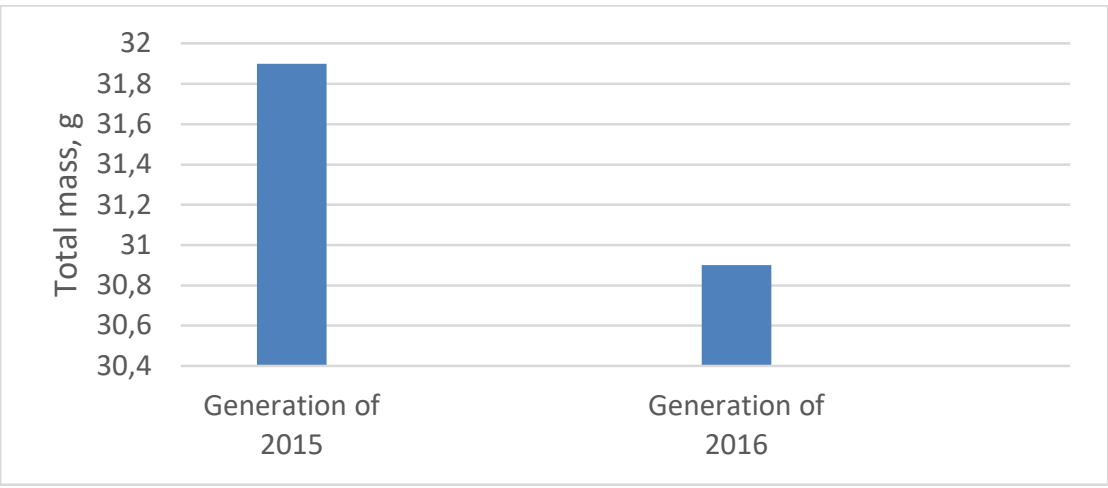

Fig. 10. Average values of the total mass of the Primorsky scallop yearlings

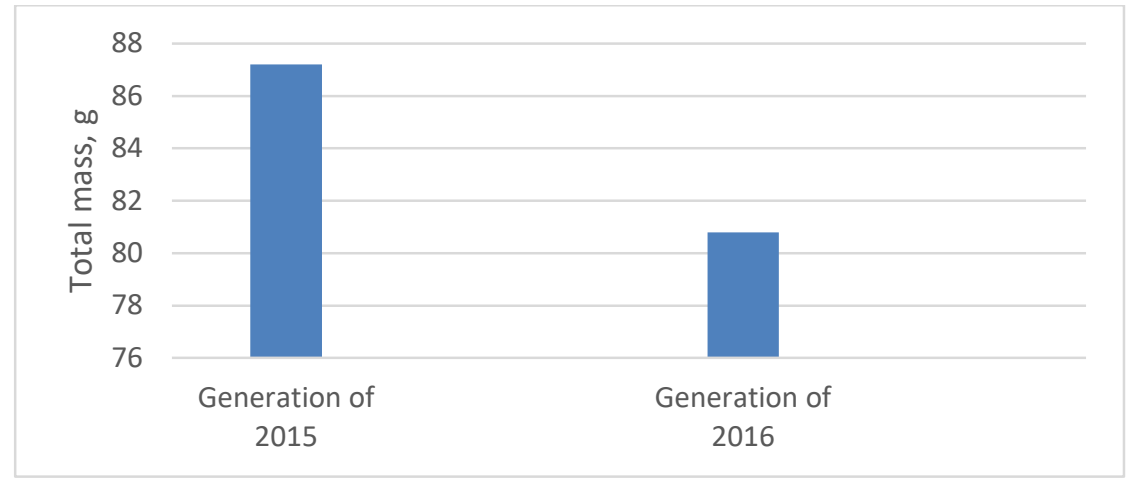

Fig. 11. Average values of the total mass of the Primorsky scallop two-year-olds 


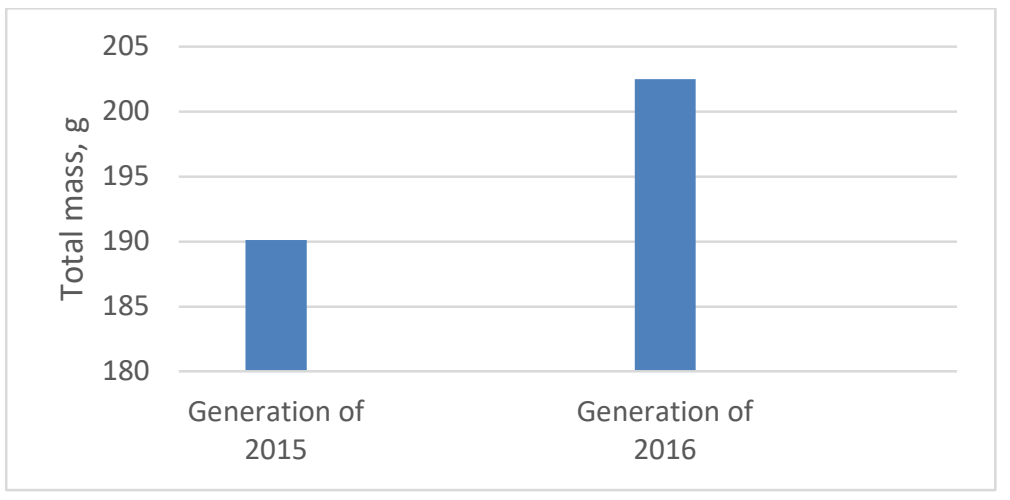

Fig. 12. Average values of the total mass of the Primorsky scallop three-year-olds

In general, the size and weight characteristics of the Primorsky scallop of studied generations correspond to the normative indicators of growth, which indicates favorable living conditions for cultivated mollusks.

\section{Conclusions}

As a result of the research, the following conclusions can be made. The size composition of the Primorsky scallop from Kozmino bay of the 2015 generation varied from 31 to 126 $\mathrm{mm}$; the average shell heights were $41.5 \pm 0.29 \mathrm{~mm}$ for yearlings, $78.9 \pm 0.5 \mathrm{~mm}$ for twoyear-olds, and $109.7 \pm 0.69 \mathrm{~mm}$ for three-year-olds. The 2016 generation included specimens with shell heights of 37 to $132 \mathrm{~mm}$. The average value for yearlings was $43.63 \pm$ $0.21 \mathrm{~mm}$, for two-year-olds $-82.9 \pm 0.51 \mathrm{~mm}$, for three-year-olds $-111.4 \pm 0.68 \mathrm{~mm}$.

The weight composition of the Primorsky scallop from Kozmino bay of the 2015 generation varied from 20 to $287 \mathrm{~g}$. The average value of the total weight for yearlings was $31.9 \pm 0.4 \mathrm{~g}$; for two-year-olds $87.2 \pm 1.3 \mathrm{~g}$, for three-year-olds $190.1 \pm 3 \mathrm{~g}$. For the 2016 generation, there were individuals with total weights of 21 to $332 \mathrm{~g}$. The average value for yearlings was $30.9 \pm 0.3 \mathrm{~g}$, for two-year-olds $-80.8 \pm 0.6 \mathrm{~g}$, for three-year-olds $-202.5 \pm 3$ g.

The dependence of shell height - total mass of the Primorsky scallop is described by the equations of a power function with a high approximation coefficient: for the generation of 2015,2016 : for yearlings $\mathrm{y}=0,0807 \mathrm{x}^{1,6047} \mathrm{R}^{2}=0,9632 ; \mathrm{y}=0,0102 \mathrm{x}^{2,1216} \mathrm{R}^{2}=0,9315$. For twoyear-olds: $y=0,0041 x^{2,277} R^{2}=0,9867 ; y=0,1731 x^{1,3905} R^{2}=0,9454$. For three-year-olds: $y=0,0004 x^{2,7655} R^{2}=0,9755 ; y=0,002 x^{2,4509} R^{2}=0,9869$.

Among the mollusks of both generations, males prevailed in two-year-olds, and females in three-year-olds.

A comparative analysis of some size and weight characteristics of individuals of the same age of different generations showed that in the 2016 generation, the average shell height was slightly higher, but at the same time the average value of the total mass was higher for mollusks of the 2015 generation.

Studies carried out in Kozmino bay under the program of integrated ecological monitoring show the species diversity of marine biota, the absence of disturbances in the development of hydrobionts, and the presence of types of indicators of pure water $[1,3,6$, 7]. Every year in the bay there is a massive spawning of scallop kept in cages, which indicates a favorable ecological situation in the water area. The biochemical parameters of the Primorsky scallop from Kozmino bay do not differ from those of mollusks that live in relatively clean waters with no anthropogenic load $[1,3,6,7]$. The results of our study 
indicate that the activity of the oil-loading enterprise does not adversely affect the main biological indicators of the Primorsky scallop cultivated in Kozmino bay.

\section{References}

1. N.A. Vykhodtseva, E.A. Kostina, E.S. Ukolova, Science and technology of pipeline transportation of oil and oil products, 1, 1-5 (2014)

2. D. M. Lowe, M. N. Moor, K. R. Clarke, Aquat. Toxicol., 1, 213-226. (1981)

3. N.A. Vykhodtseva, E.A. Kostina, E.S. Ukolova, Science and technology of pipeline transportation of oil and oil products, 1, 1-9 (2016)

4. M.A. Vashchenko, P.M. Zhdan, Pacific medical journal, 2, 110-114 (2012)

5. O.V. Stepanyan, G.M. Voskoboinikov, Marine biology, 32 (4), 241-248 (2006)

6. Final report on technological study on the topic "Technology of using the marine hydrobionts for environmental monitoring of the state of the water area of the Kozmino bay in the area of the oil terminal of Special marine oil port Kozmino Ltd. " for 2013 under the contract No. 506 П/TP/02-41/2012.

7. D.P. Chepelyansky, Ecological Bulletin, 3 (2019)

8. J.M. Lawrence, L.R. Plank, A.L. Lawrence, Comp. Biochem. Physiol, 134A, 69-75 (2003)

9. A.J. Lawrence, J.M. Soame, The effects of climate change on the repro-duction of coastal invertebrates, IBIS, 146 (1), 29-39 (2004)

10. E. Marzinelli, G. Bigatti, J. Gimenez, P. Penchaszadeh, Argentina. Bull. Mar. Sci., 79, 127-136 (2006)

11. I. Monirith, D. Ueno, S. Takahashi, et al. Mar. Pollut. Bull, 46, 281-300 (2003)

12. F. Quiniou, M. Guillou, A. Judas, Mar. Pollut. Bull., 38, 401-406 (1999)

13. A.N. Sastry, Physiology and ecology of reproduction in ma-rine invertebrates, Physiological ecology of estuarine organisms. Columbia: Univ. South Carolina Press, 279-299 (1978)

14. K.M. Wasson, S.A. Watts, Reproductive endocrinology of sea ur-chins, Edible sea urchins: biology and ecology ed. J.M. Lawrence. Elsevier Science B.V., $43-57$ (2001)

15. P.M. Zhadan, M.A. Vawenko, T.N. Alımjashova, E.N. Slinko, The monitoring of the environmental status of coastal ecosystems of the Amur Bay (Peter the Great Bay, the Japan sea) on the biological and biogeochemical parameters, Sostojanie morskih jekosistem, nahodjawihsja pod vlijaniem rechnogo stoka. Vladivostok: Dalnauka, 201227 (2005)

16. V.L. Kasjanov, L.A. Medvedeva, S.N. Jakovlev, Ju.M. Jakovlev, The reproduction echinoderms and bivalves. M.: Nauka, 207 (1980)

17. P.A. Motavkin, Ju.S. Hotimchenko, I.I. Deridovich, The regula-tion of breeding and biotechnology produce gametes in bivalve molluscs. M.: Nauka, 217 (1990)

18. Ju.S. Hotimchenko, I.I. Deridovich, P.A. Motavkin, The reproductive biology and regulation of gametogenesis and spawning in echinoderms. M.: Nauka, 168 (1993)

19. Y. Agatsuma, Ecology of Strongylocentrotus intermedius Edible sea urchins: biology and ecology ed. J.M. Lawrence. Amsterdam: Elsevier, 427-441 (2007)

20. D.W.T. Au, C.Y. Lee, K.L. Chan, R.S.S. Wu, Environ. Pollut., 111, 1-9 (2001)

21. V.M. Voropaev, A.A. Strahov, Zoologicheskij zhurnal, 56 (8), 1260-1262 (1977) 
22. M.A. Vawenko, P.M. Zhadan, Biol. Morja, 21 (6), 369-371 (1995)

23. G.S. Gavrilova, L.N. Kim, TINRO Bulletin, 185, 241-245 (2016)

24. L.A. Gaiko, Influence of environmental factors on the yield of the Primorsky scallop in mariculture farms. Fisheries Research of the World Ocean: Proceedings of the II International Scientific Conference, 1, 137-139 (2012)

25. A.V. Kucheryavenko, A.P. Zhuk, Instructions on the technology of cage and bottom cultivation of the scallop. Pacific Fisheries Research Center, 49 (2011)

26. A.P. Zhuk, Organization of an ecological mariculture enterprise for growing scallop in the Peter the Great Bay: guidelines, 114 (2018)

27. V.G. Markovtsev, Yu.E. Bregman, V.F. Przhemenetskaya, Cultivation of Pacific invertebrates and algae, 192 (1987)

28. P.A. Moiseev, A.F. Karpevich, O.D. Romanycheva, Marine aquaculture, 250 (1985)

29. G.S. Gavrilova, A.V. Kucheryavenko, Productivity of plantations of bivalve molluscs in Primorye: monograph. Pacific Fisheries Research Center, 112 (2011)

30. G.S. Gavrilova, A.V. Kucheryavenko, A.M. Odintsov, TINRO Bulletin, 147, 385-396 (2006) 